International Journal of Education and Practice

2021 Vol. 9, No. 2, pp. 424-439.

$\operatorname{ISSN}(e): 2310-3868$

$\operatorname{ISSN}(p): 2311-6897$

DOI: $10.18488 /$ journal.61.2021.92.424.439

(C) 2021 Conscientia Beam. All Rights Reserved.

check for
updates

\title{
E-LEARNING AND ACADEMIC PERFORMANCE DURING COVID-19: THE CASE OF TEACHING INTEGRAL CALCULUS
}

\author{
(D) Yani Ramdani ${ }^{1+}$ \\ Wan Hanum \\ Suraya Wan \\ Mohamed $^{2}$ \\ Nia Kurniati Syam ${ }^{3}$
}

\author{
'Faculty of Math and Science Universitas Islam Bandung, Bandung, \\ Indonesia. \\ Email.yaniramdani66@gmail.com \\ ${ }^{2}$ Faculty of Education \& Languages, Open University Malaysia, Ipoh \\ Branch, Perak. Malaysia. \\ ${ }^{3}$ Faculty of Dakwah Universitas Islam Bandung, Bandung, Indonesia.
}

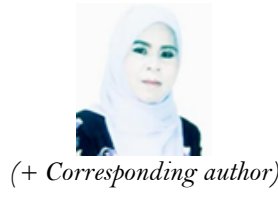

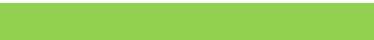

\section{ABSTRACT}

Article History

Received: 8 December 2020 Revised: 19 March 2021 Accepted: 16 April 202 Published: 3 May 2021

Keywords

Covid-19

e-learning

Academic performance

Self-efficacy

Perception of creativity

Productive disposition

Path analysis

Indonesia.
This study investigates the impact of implementing integral calculus lectures which were originally very suitable in face-to-face delivery, but during the Covid-19 pandemic situation, these were delivered online through e-learning. This research analyzes the correlation between self-efficacy, creativity perception, and productive disposition towards academic performance using path analysis and was modeled in the form of regression equation. This study involved 108 students (35 males and 72 females) at a university in Bandung, West Java, Indonesia. The research instrument used was questionnaire of self-efficacy (11 items), creativity perception (15 items) and mathematical disposition (14 items). All research variable items had a Pearson correlation ( $\mathrm{r}$ ) greater than 0.25 , so all items were said to be valid. The reliability coefficient of Cronbach's Alpha for self-efficacy, perceived creativity, and productive disposition were included in the high category. The results showed a correlation between self-efficacy and creativity perception with regard to productive disposition. There was also a direct correlation between self-efficacy and academic performance. Creativity perception did not show a direct influence on academic performance nor. Productive disposition had a direct influence on academic performance. There was a correlation between self-efficacy, creativity perception, and productive disposition of academic performance. Self-efficacy (happy to help other friends, dare to face criticism and challenges, and dare to compete to win a competition) had the largest contribution to academic performance while creativity perception (creative ideas must be sophisticated and complex, creative people have high curiosity, creative people find it difficult to accept different opinions from others, creativity can only be developed in certain people, and creativity comes over by chance) has the smallest one. These findings can be used as first step in understanding creative perception as a weak contribution to cognitive abilities about academic performance, even though creativity has an important role in developing mathematics performance.

Contribution/Originality: The originality of this study lies in it investigating the impact of implementing integral calculus lectures through e-learning during the Covid-19 pandemic. It shows how the application of elearning can encourage students to engage and manage learning independently and learn in a practical way. Factors like self-efficacy and perception of creativity have been analyzed to determine how they affected students' academic performance. 


\section{INTRODUCTION}

COVID-19 is now an epidemic that is feared by mankind because of its rapid spread. Coronaviruses have caused two new epidemics namely SARS and MERS. The map of the spread of COVID-19 reaches almost all over the world. Currently the United States, Italy and Spain are the countries with the largest cases outside China. This pandemic situation has an impact on the life order of people around the world and has even become a threat to the health sector, the economic sector, the social sector, the cultural sector, the religious sector, including the education sector. Indonesia is one of the countries with the highest number of positive COVID-19 cases in Southeast Asia. The growth rate of positive COVID-19 patients in Indonesia continues to increase until now. The education sector was significantly affected because many activities involved face-to-face such as the teaching and learning process, the academic mentoring process, scientific meetings and so on. To prevent the spread of COVID-19, the Education Ministry and Culture issued a Circular of the Education Ministry and Culture Number 3 of 2020 concerning Prevention of COVID-19 in the Education Unit, and Number 36962/MPK.A/HK/2020, so that teaching and learning activities must be carried out in an online manner. A total of 834 universities in Indonesia were forced to migrate online with an adaptation time tolerance of around 25 days after the announcement of positive Covid-19 patients. In general, Indonesia has not been able to fully carry out distance learning due to limited facilities and human resources to use fully online learning. The COVID-19 pandemic situation does not allow face-to-face instruction, as a result, learning must fully switchover to online methods.

Adaptation and migration by utilizing technology must be facilitated by higher educations, one of which is elearning. The implementation of E-leaning becomes hopes and challenges. E-learning is seen as an innovative approach to the delivery of educational services via electronic in the form of information that enhances the knowledge, skills and other outcomes of students (Fazlollahtabar \& Muhammadzadeh, 2012). Integral calculus learning is generally carried out face to face. In face-to-face learning, integral calculus material is still a big challenge because the abstract material, require distinctive symbols and language, a high level of logic, and a high level of accuracy and formalism. In general, students can receive collaborative learning through online and face-toface interactions and there is no significant difference between e-learning and other project values (Wakeford, 2011). The Covid-19 pandemic situation forces lecturers and students to carry out the instructional process through e-learning.

E-learning technology in integral calculus learning is certainly still a new paradigm. This condition becomes very challenging (Figueroa-Cañas \& Sancho-Vinuesa, 2018). Some researchers argue that not all educational services via e-learning affect the overall quality of instructional outcomes in the same way. Awareness of technology, motivation, and change of student behavior are terms and conditions for successful e-learning implementation (Bhuasiri, Xaymoungkhoun, Zo, Rho, \& Ciganek, 2012). The implementation of fully e-learning can affect student attitudes and learning achievement. Personality factors such as attitudes, self-efficacy, anxiety, and computer experiences have become determinants that underlie behavior to accept and use technology (Bervell \& Umar, 2017). Self-efficacy has effect of positive towards on face-to-face instruction but on online instructional is less clear (Prior, Mazanov, Meacheam, Heaslip, \& Hanson, 2016). Perceptions of creativity will encourage students to be creative and will then become talents to master creative IT (Zhou, Chen, \& Luo, 2014).

In the implementation of e-learning in science, the results showed that there was no significant increase in student creativity, but these results are limited by the small sample size, time and volume of work on students (Wakeford, 2011). Perceptions of competence and ability to use ICT are significantly related to interest in science, self-efficacy in science, and productive dispositions of science, while perceptions of student mastery in using ICT are more closely related to student dispositions than student competence (Areepattamannil \& Santos, 2019). In mathematics learning, students who are heavily involved in learning (e-learning) get the best scores in self-efficacy and academic performance (Wang, Liang, Lin, \& Tsai, 2017). 
Low self-efficacy can even cause disruption in academic regulation such as paying attention during class, failing to prepare for exams and even dropping out of school (Zimmerman \& Cleary, 2006). Productive disposition is an important concern in education because it provides a unique additional variant on cognitive abilities (Ku \& Ho, 2010). Skill and disposition have a contribution to academic performance (Talsma, Schüz, Schwarzer, \& Norris, 2018). Self-efficacy, creativity perception, productive disposition, and academic performance are important in calculus, but research that studies the impact of affective aspects of student experience, such as self-efficacy in proving mathematics (Iannone \& Inglis, 2010) development of mathematical creativity (Wang et al., 2017) and the development of productive disposition instruments (mathematical dispositions) (Quinn, Hogan, Dwyer, Finn, \& Fogarty, 2020) are still relatively limited.

Based on the above conditions, it is necessary to analyze the influence of students' emotional state on academic performance after learning to understand the true effect of implementing e-learning in integral calculus learning. The purpose of this study was to analyze the correlation between self-efficacy, creativity perception, productive disposition, and student academic performance through the application of E-learning. This included: (1) the direct effect of self-efficacy on creativity perception. (2) self-efficacy and creative perception on productive disposition. (3) self-efficacy, creativity perception and productive disposition on academic performance.

\section{LITERATURE REVIEW}

This study investigates the impact of self-efficacy, creativity perception, productive disposition on academic performance in the implementation of integral calculus lectures which were originally very suitable to be delivered face-to-face, but in the covid-19 pandemic situation, they must be delivered by e-learning methods. Mental acuity has been consistently shown to predict academic achievement (Pluck, 2016). Academic achievement includes both cognitive and non-cognitive factors. Current research is increasingly directed at the role of non-cognitive factors on cognitive factors, such as self-discipline and emotional intelligence on academic performance (Thomas, Cassady, \& Heller, 2017). Self-discipline and emotional intelligence include self-efficacy, creativity, disposition, independent learning, critical thinking, creativity thinking and so on.

\subsection{E-Learning}

E-learning is an electronic learning model via the internet, internal network (intranet), multimedia such as CDs, DVDs, and others. E-learning is the application of networks to facilitate learning, including the production, delivery and acquisition of learning content, management of learning experiences, and information exchange between learning communities (Levina, 2017). The adoption of electronic media such as computers and networks in delivering information to their recipients allows students to interact with learning content, teachers, and their friends. The use of all types of technology in delivering information to students electronically or via internet portals either remotely or in the classroom is important and more beneficial for universities and students (Bhuasiri et al., 2012). Mathematics e-learning systems in higher education can increase participation and learning outcomes. The SCNC1111 e-learning platform can improve understanding and better ability in calculus knowledge. (Liang, Yeung, Lui, Cheung, \& Lam, 2018).

In learning basic calculus at the University of Helsinki, students learning through e-learning have a lower dropout rate than students with conventional learning. Their posttest scores were also better than conventional students (Seppala, Caprotti, \& Xambó, 2006). There is a relationship between the quiz score and the final score in learning calculus which is carried out asynchronously through the online calculus module (Figueroa-Cañas \& Sancho-Vinuesa, 2018). When remedial mathematics learning is not integrated with ICT, students' posttest scores are not significantly higher, but after implementing integrated mathematics learning with ICT, the posttest scores are significantly higher (Chen \& Wu, 2020). 
2.2. Self-Efficacy

Self-efficacy generally refers to a person's belief in himself to evaluate the ability to perform certain behaviors under certain circumstances (Pajares \& Miller, 1994). Individuals can develop self-efficacy by using cognitive use, making strategies and managing themselves in different dimensions (Chemers, $\mathrm{Hu}$, \& Garcia, 2001). One of the selfefficacy competencies is operating a cognitive process to predict problems and decide how to deal with them (Bandura, 1989). There is a positive relationship between mathematics interest and mathematics achievement which is mediated by self-efficacy. Online statistics lessons increased self-efficacy ratings $(\mathrm{d}=0.696)$ (Huang, Chang, \& Chou, 2020). Dynamic visualization-based learning through the use of Geogebra technology applications increases high-level mathematical self-efficacy in real time (Kohen, Amram, Dagan, \& Miranda, 2019). Positive student attitudes and digital literacy significantly contribute to self-efficacy so that self-efficacy has become an important determinant of learning success (Prior et al., 2016). Self-efficacy is a determinant of student learning behavior (Bandura, 2010).

\subsection{Creativity Perception}

Creativity is one of the important $21^{\text {st }}$ century skills that need to be developed in students because we live in an era that is always changing and unpredictable (Akyildiz \& Celik, 2020). The process of developing creativity is supported by experience, interaction with teachers, friends and the environment around them. The relationship between mathematical creativity with each attitude and environmental characteristics is positive and significant. Besides, there is a positive relationship between mathematical creativity and attitudes and environmental characteristics (Kanhai \& Singh, 2017). Mathematical achievement was the strongest predictor in math creativity scores (Mann, 2009). The results showed that a significant dominant causal relationship was found between mathematical creativity and mathematical performance. This shows that mathematical performance was found to be the cause of mathematical creativity rather than the opposite (Tyagi, 2016). In this research, the aspects of perceptions of creativity that are studied are creative potential, scope of creativity, characteristics of creative ideas, characteristics of creative individuals, and creativity development. Individual creativity can be mediated through creative self-efficacy (Chang, Wang, \& Lee, 2016). Creative self-efficacy and creative performance have a positive correlation (Puente-Díaz \& Cavazos-Arroyo, 2017). Creativity plays an important role in learning (Beghetto, 2016).

\subsection{Productive Disposition}

Disposition is defined as a measure of students' attitudes and beliefs towards mathematics (Royster, Kim Harris, \& Schoeps, 1999). Mathematical dispositions or productive dispositions are the tendency to view mathematics as something that is easy to understand, feel mathematics as a useful science, believes that diligent and tenacious efforts in learning mathematics pay off, and performs mathematics-based activities (Kilpatrick, Swafford, \& Findell, 2001). Eight dimensions of mathematical productive disposition have a statistically significant contribution of $84.3 \%$ to the prediction of mathematics achievement (Awofala, Lawal, Arigbabu, \& Fatade, 2020). Mathematical disposition which is a part of critical thinking skills that allow generating arguments or solutions to get logical conclusions (Dwyer, Hogan, Harney, \& Kavanagh, 2017; Dwyer, Hogan, \& Stewart, 2014) are often associated with academic performance (Stupnisky, Renaud, Daniels, Haynes, \& Perry, 2008).

Critical thinking disposition is also a predictor of critical thinking performance (Dwyer et al., 2014). Dispositions have been suggested to play an important role in student learning. Disposition affects a person's willingness to use and monitor critical thinking skills (Giancarlo \& Facione, 2001). Productive dispositions can influence learning and performance. They usually determine how well students motivate themselves and endure adversity. They also influence choices about courses and even educational and career paths. The aspects of productive disposition in research include: (1) self-confidence, (2) tenacity or persistence, (3) flexibility and openmindedness, (4) interest and curiosity, and (5) the tendency to monitor thinking processes and own performance. 
Disposition is an important aspect of critical thinking skills because the application of skills is very dependent on the disposition used. Future research will require efforts to examine predictors and outcomes based on skills and disposition-based aspects of creative thinking (Quinn et al., 2020).

\subsection{Academic Performance}

Academic performance, learning outcomes, or learning achievement express the same meaning of student academic learning outcomes. Self-efficacy is a predictor of motivation orientation and math performance, and for Hispanic students there is a strong relationship between previous math achievement and self-efficacy (Stevens, Olivarez, Lan, \& Tallent-Runnels, 2004). Self-efficacy and mastery of science are significant predictors of predicting results on the final exam (Vogel \& Human-Vogel, 2016). Mathematical achievement is an effective supporter of the performance of tests of mathematical creativity (Huang, Peng, Chen, Tseng, \& Hsu, 2017).

\subsection{E-Learning, Self-Efficacy, Creativity Perception, Productive Disposition, and Academic Performance}

Sansome (2016) states that mathematical competence is very important in the concept of mathematical proof, only a few students try to prove it because of the lack of self-efficacy to identify. The competitive model of creativity has been widely used to study creative self-efficacy (Sangsuk \& Siriparp, 2015; Wagster, Tan, Wu, Biwas, \& Schwartz, 2007). The disposition of attention to truth can increase the variant of critical thinking which is a cognitive ability in China (Ku \& Ho, 2010). The critical thinking disposition can predict a higher level of controlling for academic performance (Stupnisky et al., 2008). Higher critical thinking skills or dispositions are positively correlated with better learning outcomes even though the level of the relationship between them is unclear (Niu, Behar-Horenstein, \& Garvan, 2013; Stupnisky et al., 2008; Thompson, 2009). Creative thinking dispositions display only weak to moderate correlations with measures of general cognitive ability (Macpherson \& Stanovich, 2007; Zeidner \& Matthews, 2000)). Thompson (2009) reported a fairly strong correlation $(r=0.62)$ between creative thinking dispositions and student academic performance. Skills and dispositions make unique contributions to academic performance (Talsma et al., 2018) and non-verbal intelligence is related to academic achievement (Malykh, 2017).

\subsection{Research Hypotheses}

The variables observed in this study were self-efficacy $\left(\mathrm{X}_{1}\right)$, creativity perception $\left(\mathrm{X}_{2}\right)$, productive disposition (X3) and academic performance (X4). The hypotheses tested are:
$H_{1}$ : Self-efficacy contributes positively to creativity perception.
$\mathrm{H}_{2}$ : Self-efficacy contributes positively to productive disposition.
$H_{s}$ : Creativity perception positively contribute to productive disposition.

$H_{4}$ : Self-efficacy and creativity perceptions contributes positively to productive dispositions.

$H_{5}$ : Self-efficacy contributes positively to academic performance.

$H_{6:}$ Creativity perceptions contributes positively to academic performance.

$H_{7:}$ Productive dispositions contribute positively to academic performance.

$H_{s:}$ Self-efficacy, creativity perception, and productive disposition contribute positively to academic performance.

\section{METHOD}

Undergraduate students majoring in mathematics are required to understand basic principles of integral calculus which demand higher abstract thinking skills, such as defining and calculating lengths, widths, volumes consisting of the volume concepts of rotating objects, work, moment, and the center of mass using the concepts of integral. The subject of integral calculus in Indonesian higher education includes definite integral, continuous function integral, integration of algebraic functions, integral characteristics, integration techniques, partial integral, 
and applications of integrals. The subject is delivered to improve students' higher thinking skills which cover understanding, problem solving, communicating, reasoning, and mathematical connection. The subject was previously given in face-to-face mode. However, due to the pandemic of COVID-19, it is now delivered online, and thus it is necessary to investigate the effect of online delivery of integral calculus subject on students' attitude and performance.

\subsection{Learning Outcomes}

The subject of integral calculus was offered in one semester with four credit hours (three hours for theoretical foundation and one hour for practical). The first six meetings were delivered in the classroom using a face-to-face mode from January to February 2020 and the next nine meetings were given online from March to June 2020. The main textbook used in this subject was Indonesian version of D. Varberg, EJ Purcell, and SE Rigdon, Calculus, 9th edition. New York: Pearson. Table 1 presents the learning outcomes of this course as specified in the curriculum.

Table-1. Learning outcomes of the course

\begin{tabular}{c|l}
\hline $\begin{array}{c}\text { Learning } \\
\text { outcomes (LO) }\end{array}$ & Description: \\
\hline LO 1 & $\begin{array}{l}\text { Students are expected to understand the concepts of integral calculus, covering the } \\
\text { ability to express the concepts correctly using their own words, the ability to identify } \\
\text { correct and incorrect concept applications, and the ability to interpret the concepts in } \\
\text { various situations and use the concepts correctly. }\end{array}$ \\
\hline LO 2 & $\begin{array}{l}\text { Students are expected to master technical skills, such as the ability to apply various } \\
\text { mathematical manipulations correctly. }\end{array}$ \\
\hline LO 3 & $\begin{array}{l}\text { Students are expected to develop logical reasoning skills, such as the ability to provide } \\
\text { logical reasons in every action or step, to question something new, and to find out } \\
\text { answers with logical reasons. }\end{array}$ \\
\hline
\end{tabular}

Based on Table 1, academic achievement in this study referred five intertwined mathematical competencies by Kilpatrick et al. (2001). The competencies include (1) concept understanding (understanding the concepts of operations and relations), (2) concept applications, (3) strategic competence, (4) adaptive reasoning and, (5) productive dispositions. Academic achievement has been predicted by a number of factors, such as mental focus (Pluck, 2016) and factors of non-cognitive like self-discipline and emotional intelligence (Thomas et al., 2017). Emotional intelligence factors include self-efficacy, creativity, autonomous learning, critical learning, and many others.

\subsection{Measures}

This survey study aims to investigate undergraduate students' perceptions on online delivery of integral calculus subject. The first survey was administered to examine perceived self-efficacy, creativity, and productive dispositions among students in relation to online learning. The measures used in this study (Table 2, Table 3 and Table 4) consisted of self-efficacy (11 items), perception of creativity (15 items), and productive disposition (14 items). Each level of agreement on the statement was measured by using a 5-point Likert scale in which 1 indicated 'Strongly Disagree' and 5 indicated 'Strongly Agree'. Academic performance in this study was taken from the scores of final examinations.

All Self-efficacy variable items have a Pearson correlation ( $\mathrm{r}$ ) greater than 0.25 then all items are said to be valid. Cronbach's Alpha reliability coefficient value for each item is between $0.70-0.10$ meaning that each item $\mathrm{X}_{1}$ is included in the high category. All tests are internally consistent with a strong reliability value of 0.795.

Table 3 shows the results of the calculation of the validity and reliability test of each item of perception data on creativity. 
Table-2. Items of self-efficacy.

\begin{tabular}{|c|c|c|c|}
\hline $\begin{array}{c}\text { Item } \\
\text { number }\end{array}$ & Item description & $\begin{array}{c}\text { Pearson } \\
\text { Correlations }\end{array}$ & $\begin{array}{l}\text { Cronbach's Alpha } \\
\text { if Item Deleted }\end{array}$ \\
\hline 1 & I'm nervous when answering a teacher question & 0.587 & 0.777 \\
\hline 2 & $\begin{array}{l}\text { I'm not sure if I can complete a complex task } \\
\text { successfully }\end{array}$ & 0.559 & 0.777 \\
\hline 3 & I'm sure I will pass the exam & 0.507 & 0.772 \\
\hline 4 & I'm satisfied with what I have achieved & 0.564 & 0.780 \\
\hline 5 & I'm afraid of expressing different opinions with others & 0.524 & 0.701 \\
\hline 6 & I can accept different opinions from others & 0.521 & 0.752 \\
\hline 7 & I'm proud to participate in every activity & 0.595 & 0.735 \\
\hline 8 & I'm happy to help other friends & 0.615 & 0.732 \\
\hline 9 & I dare to face criticism and challenges & 0.576 & 0.798 \\
\hline 10 & I’m afraid other friends know my weaknesses & 0.556 & 0.715 \\
\hline 11 & I dare to compete to win in a competition & 0.543 & 0.747 \\
\hline
\end{tabular}

Table-3. Items of creativity perceptions

\begin{tabular}{|c|c|c|c|}
\hline $\begin{array}{c}\text { Item } \\
\text { number }\end{array}$ & Item description & $\begin{array}{c}\text { Pearson } \\
\text { Correlation }\end{array}$ & $\begin{array}{l}\text { Cronbach's } \\
\text { Alpha if Item } \\
\text { Deleted }\end{array}$ \\
\hline 1 & Only genius people can be creative people & 0.330 & 0.734 \\
\hline 2 & Anyone can be creative person & 0.349 & 0.731 \\
\hline 3 & $\begin{array}{l}\text { Creativity is necessary in our aspects of life, including } \\
\text { mathematics }\end{array}$ & 0.502 & 0.735 \\
\hline 4 & Creative ideas must be sophisticated and complex & 0.410 & 0.730 \\
\hline 5 & $\begin{array}{l}\text { Creativity is produced by combining, changing, or refining } \\
\text { existing ideas }\end{array}$ & 0.562 & 0.707 \\
\hline 6 & New ways to solve problems can be viewed as creative ways & 0.503 & 0.725 \\
\hline 7 & Discipline can hinder creativity & 0.403 & 0.729 \\
\hline 8 & Creative people dare to try new things & 0.461 & 0.752 \\
\hline 9 & Creative people have higher curiosity & 0.397 & 0.723 \\
\hline 10 & Creative people are not afraid of failure & 0.401 & 0.733 \\
\hline 11 & $\begin{array}{l}\text { Creative people are difficult to accept different opinions from } \\
\text { others }\end{array}$ & 0.375 & 0.747 \\
\hline 12 & Creativity can be developed by certain people only & 0.366 & 0.729 \\
\hline 13 & Challenges can push people to think creatively & 0.367 & 0.736 \\
\hline 14 & Creativity comes about by chance & 0.432 & 0.732 \\
\hline 15 & Mathematics learning can be used to developed creativity & 0.467 & 0.737 \\
\hline
\end{tabular}

Table-4. Items of productive disposition

\begin{tabular}{|c|c|c|c|}
\hline $\begin{array}{c}\text { Item } \\
\text { number }\end{array}$ & Item description & $\begin{array}{c}\text { Pearson } \\
\text { Correlation }\end{array}$ & $\begin{array}{l}\text { Cronbach's Alpha } \\
\text { if Item Deleted }\end{array}$ \\
\hline 1 & I'm sure I can get the best grade & 0.567 & 0.700 \\
\hline 2 & I'm sure I can complete assignments & 0.592 & 0.792 \\
\hline 3 & $\begin{array}{l}\text { I ask questions when I find difficulties in solving the } \\
\text { problems }\end{array}$ & 0.500 & 0.716 \\
\hline 4 & I re-read learning materials & 0.572 & 0.745 \\
\hline 5 & I study the materials in advance & 0.454 & 0.731 \\
\hline 6 & I consider many possibilities before making decisions & 0.452 & 0.780 \\
\hline 7 & $\begin{array}{l}\text { I'm sure there are many ways to solve problems beside the } \\
\text { one taught by the lecturer }\end{array}$ & 0.511 & 0.749 \\
\hline 8 & I'm sure that changing opinions show weaknesses & 0.518 & 0.713 \\
\hline 9 & I study on my own & 0.566 & 0.760 \\
\hline 10 & I feel challenged to solve difficult tasks & 0.537 & 0.735 \\
\hline 11 & I study textbooks other than the one used in the classroom & 0.566 & 0.757 \\
\hline 12 & I set learning targets & 0.565 & 0.760 \\
\hline 13 & I compare learning achievement with the set targets & 0.538 & 0.757 \\
\hline 14 & I try to know my strengths and weaknesses in learning & 0.531 & 0.786 \\
\hline
\end{tabular}


All items of perception of creativity have a Pearson correlation ( $r$ ) with a total score of each item greater than 0.25 then all items are said to be valid. Cronbach's Alpha reliability coefficient value for each item is between 0.70 0.10 meaning that each item $X_{2}$ is included in the high category. All tests are internally consistent with a strong reliability value of 0.744 . Table 4 is the calculating result of the validity and reliability of each productive disposition item.

All productive Disposition items have a Pearson correlation $(r)$ greater than 0.25 then all items are said to be valid. Cronbach's alpha reliability coefficient for each item is between $0.70-0.10$ meaning that each $\mathrm{X}_{3}$ item is included in the high category. All tests are internally consistent with a strong reliability value of 0.710 .

\subsection{Sample}

This study involved 108 student participants ( 35 males; 73 females) who were selected based on convenient sampling (Cohen, Manion, \& Morrison, 2007). These participants were enrolled in the subject of Integral Calculus and were divided into three groups (22 high achievers, 63 middle achievers, and 23 low achievers) based on their achievement in the topic of Calculus Differential. They studied in the second year at one university in Bandung, West Java, Indonesia, and came from different types of high schools: general, vocational, and Islamic high schools. The schools have different mathematics curriculum resulting in differences in student performance. The focus of general high schools and Islamic high schools, for example, was more towards understanding mathematical concepts and techniques while vocational schools focused more on understanding the concepts and their applications.

\section{RESULTS}

One-way analysis of variance (ANOVA) was conducted to examine the effect of self-efficacy (X1), creativity perception (X2), productive disposition (X3), on student academic performance (X4). Figure 1 shows the structure of the hypothesized model that shows the correlation between the observed variables. The effect of self-efficacy on the creativity perception produces a value of $\mathrm{Sig}=0.000(<\alpha=0.05)$, so $\mathrm{H}_{1}$ is accepted. This means that there is a direct effect between self-efficacy on creativity perception. Quantitative data shows that self-efficacy has a contribution to affect creativity perception by 0.14 , while the remaining 0.76 is the contribution of other variables not studied. With a determination coefficient of 0.14 , the path coefficient value of other variables outside the model

is $\rho_{X_{z \varepsilon}}=0.872$. From the resulting regression model, it was found a positive correlation between student's selfefficacy and creativity perception, although the correlation was not too strong. Therefore, it could be interpreted that the higher is the self-efficacy, the better is the creativity perception. In other words, self-efficacy can predict perceptions of student creativity.

$\mathrm{H}_{2}$ is accepted with a value of $\operatorname{sig}=0,000$ less than $\alpha=0.05$ meaning that there is a positive correlation between self-efficacy and productive disposition. $\mathrm{H}_{3}$ is accepted with a value of sig $=0,000$ less than $\alpha=0.05$ meaning that there is a positive correlation between creativity perception towards productive disposition. The effect of self-efficacy and creativity perceptions on productive dispositions results in the value of $\operatorname{Sig}=0.000(<\alpha=0.05)$ so $\mathrm{H}_{4}$ is accepted. This means that there is a direct effect between self-efficacy and creativity perception with a productive disposition. The regression model found a positive correlation between self-efficacy and creativity perception with productive dispositions. The results show that the higher is the sense of self-efficacy and their creativity perception, the better is the value of the productive disposition. Those who scored higher on productive disposition appeared to have a stronger sense of self-efficacy belief and creativity perception. In other words, selfefficacy and creativity perception can predict students' productive dispositions. The contribution of self-efficacy, 
creativity perception, and productive disposition to academic performance is 0.082 . The coefficient of determination

obtained is 0.082 , so the path coefficient value of other variables outside the model is $\rho_{\boldsymbol{X}_{\mathbf{4 \varepsilon}}}=0.958$.

$\mathrm{H}_{5}$ is accepted with a value of $\operatorname{sig}=0,000$ less than $\alpha=0.05$, meaning there is a direct influence between selfefficacy towards academic performance. $\mathrm{H}_{6}$ is rejected with a value of sig $=0.548$ greater than $\alpha=0.05$, meaning the perception of creativity has no direct influence on academic performance. $\mathrm{H}_{7}$ is rejected with a value of sig $=0.305$ greater than $\alpha=0.05$, meaning productive disposition has no direct effect on academic performance. The effect of self-efficacy, creativity perception, and productive disposition on academic performance results in a sig $=0.029(<\alpha$ $=0.05)$, so $\mathrm{H}_{8}$ is accepted, meaning that there is a direct effect between self-efficacy, creativity perception, and productive disposition on academic performance.

The regression model found a positive correlation between self-efficacy, creativity perception, and productive disposition towards academic performance. The results show that the higher is the sense of self-efficacy, creativity perception, and productive disposition, the better is the academic performance score. Those who score higher on academic performance appear to have stronger self-efficacy, creativity perception, and productive disposition. In other words, self-efficacy, creativity perception, and productive disposition can predict student academic performance.

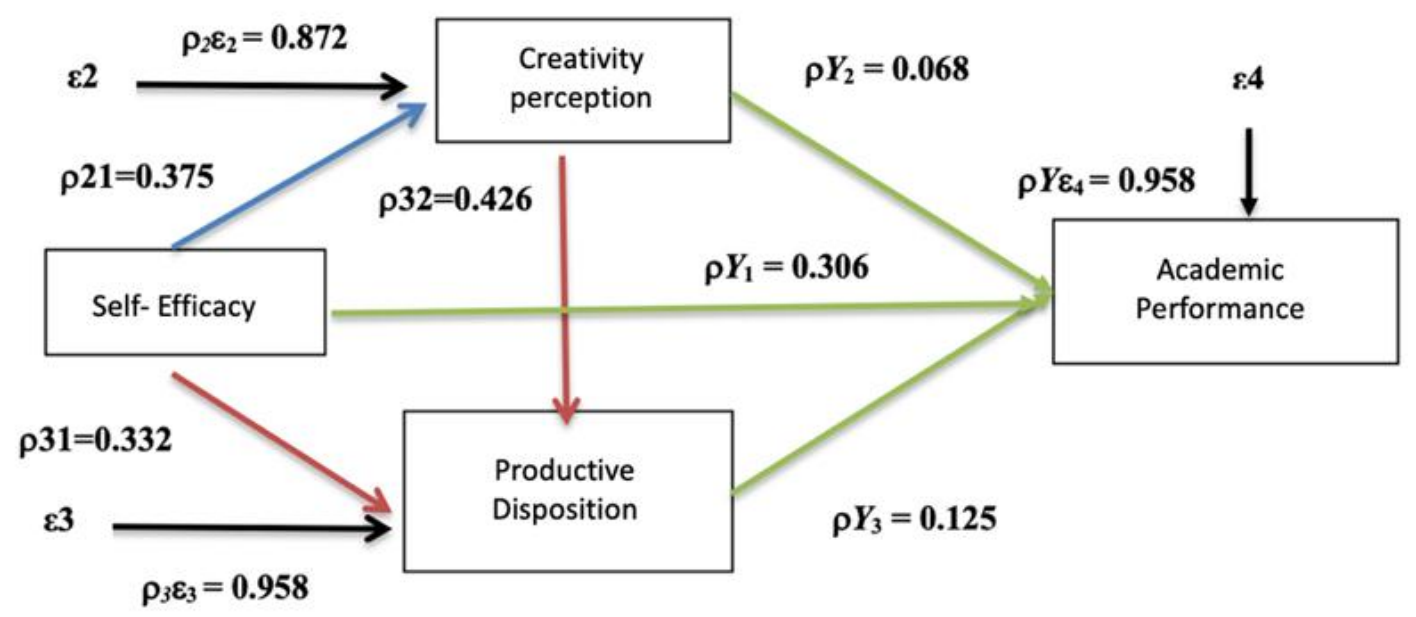

Figure-1. Structure of self-efficacy, creativity perception, productive disposition and performance academic model.

Other research results indicate that: (1) there is a positive correlation between self-efficacy and productive disposition (2) there is a positive correlation between creativity perception and productive disposition (3) there is a direct effect of self-efficacy on academic performance (4) creativity perception has no direct effect on academic performance (5) productive disposition does not have a direct effect on academic performance.

\section{DISCUSSION}

The results of hypothesis testing show that $\mathrm{H} 1, \mathrm{H} 2, \mathrm{H} 3, \mathrm{H} 4, \mathrm{H} 5$, and $\mathrm{H} 8$ were rejected. $\mathrm{H} 6$ and $\mathrm{H} 7$ were accepted. The strength of the research lies in the support of all students who are willing to be fully involved and the existence of covid-19 pandemic. The e-learning application in the situation of the spread of the Covid-19 pandemic is used to change the student mindset in learning. The development of a mindset of perceived interest and the effort given is an element of epistemic curiosity that is directly affected positively by self-efficacy of creative and has effect of positive towards learning outcome (Puente-Díaz \& Cavazos-Arroyo, 2017). 
The results also revealed that the self-efficacy factor (for example, happy to help other friends, dare to face criticism and challenges, and dare to compete to win a competition) is one of the most powerful factors to affect student academic performance. The implementation of online learning encourages students to be involved and manage learning independently. Students who are heavily involved are more likely to develop strong self-efficacy in their studies. This can have implications for the development of student skills for future industrial needs that emphasize more on process skills, namely active listening skills, logical thinking, and monitoring self and the others. The factor that has the lowest effect on improving student academic performance is the perception of creativity (For example, creative ideas must be sophisticated and complex, creative people have high curiosity, creative people find it difficult to accept different opinions from others, creativity can only be developed in certain people, and creativity comes over by chance) is still a strong perception of online learning. This is a challenge for lecturers to be more creative in order to help students to understand the meaning of creativity. Students can be given challenges in the form of problem-solving or open-ended.

These results of the study in general can strengthen previous research, which claims that self-efficacy, creativity perception, and productive disposition are important predictors for improving student academic performance. Since the effect of each variable is at $0.068<r<0.306$, it is believed that the learning system is still capable of developing students' academic performance, self-efficacy, creativity perception, and productive dispositions. This has implications for students' understanding of using the online learning system. This assumption is confirmed by the existing literature from developing countries (Cidral, Oliveira, Di Felice, \& Aparicio, 2018). E-learning is additional benefits for students to study in a practical way. Therefore, students can manifest their ideas and put them in certain sentences, which means students have study over again the information they have practiced, as students do when they prepare for certain exams. Students also prefer to take online quizzes on Edmodo because they can get immediate answers at the end of the quiz (Lau, Lam, \& Zhou, 2010). Even the low achievers seem to benefit more in generating questions than the high achiever (Berry \& Chew, 2015).

Self-efficacy has a direct effect on creativity perception of 0.375 which is defined in Model-1: $X_{2}=0,375 X_{1}+\varepsilon$. The contribution of the self-efficacy variable to creativity perception is 0.14 . Model-1 shows that self-efficacy has a significant effect on creativity perception for E-learning applications. There is a positive correlation between self-efficacy and productive disposition. There is a positive correlation between creative perceptions and productive dispositions. The contribution of self-efficacy and perception of creativity to productive disposition is 0.397 with the path coefficient value of other variables outside the model of

$\rho_{x_{s \varepsilon}}=0.777$. The direct effect of self-efficacy and creative perception on productive dispositions is 0.492 which

is defined as Model-2: $X_{3}=0,332 X_{1}+0,426 X_{2}+\varepsilon_{3}$. Model-2 shows that: (1) self-efficacy and creativity perception have a significant effect on students' productive disposition for E-learning application. (2) There is a positive correlation between self-efficacy and productive disposition. (3) There is a positive correlation between creative perception and productive disposition. Regarding observations of students' mathematical dispositions, (Maxwell, Masters, Kerr, \& Weedon, 2001) state that components of mathematical disposition such as curiosity and persistence can be recognized when students persist in completing difficult tasks, taking risks, and showing an act of being open minded. However, studies on the predictor power of problem-solving disposition and critical thinking on self-efficacy tend to be limited (Zangenehvandi, Farahian, \& Gholami, 2014).

There is a direct effect between self-efficacy and academic performance. Creative perceptions do not have a direct effect on academic performance. Productive disposition has no direct effect on academic performance. The contribution of self-efficacy, creativity perception, and productive disposition to academic performance is about 
0.082. There is a direct effect between self-efficacy, creative perception and mathematical disposition on academic performance of 0.147. The Model-3 has the forming $X_{4}=0,306 X_{1}+0,068 X_{2}+0,125 X_{3}+\varepsilon_{3}$. Model-3 shows that self-efficacy has a direct effect on improving student academic performance for E-learning applications. E-learning application, self-efficacy has a direct effect on academic performance (Van Aalderen-Smeets \& Walma van der Molen, 2018). Academic self-efficacy is not only an internal factor that affects student academic performance, but also plays an important role in regulating other factors that affect academic achievement. Selfefficacy is an important aspect of achieving extraordinary achievement in all areas explored by students; including academic.

The results show the evidence that creativity perception does not have a direct effect on improving student academic performance for E-learning applications. Creativity perception is not correlated (even with large sample sizes) with various creative problem-solving measures. In terms of correlation with other variables, creativity perception is quite significant, yet still low (Roni Reiter-Palmon, 2012). Creativity perception has a significant but low correlation with different thinking tasks (Batey \& Furnham, 2008). They also found a significant correlation between creativity perception and academic performance, although (Eisenman \& Grove, 1972). However, there are other studies showing that creativity perception is not always suitable for measuring paper-and-pencil-dependent abilities (or keyboard computers). Lee and Meara (2002) used three measures of creativity (verbal, pictorial, and self-report) and found a low association between the three measures.

The development of productive dispositions can be trained through learning mathematics. Learning mathematics is not only done to help students but to gain skills and strategies in problem solving. However, engaging mental attitudes and developing mathematical dispositions is an effective way of observing situations (Watson \& Hill, 2015). From a pedagogical perspective, it is considered an important aspect of learning mathematics to affect students' mathematical dispositions and help them to develop their self-perceptions as members of the mathematics student community (Sansome, 2016). In the strength of mathematics, students are required to be able to use communication skills, have reasoning ability, connecting mathematical ideas to solve problems, and changing positive attitudes towards mathematics.

The results revealed that productive disposition did not have a direct effect on improving student academic performance for E-learning applications. This can happen because disposition and ability are two different things. There is a positive and significant correlation between mathematical disposition and mathematics learning outcomes of high school students, although the correlation coefficient is not high (Saija, 2012). The negative disposition on mathematics has affected their performance in performing math tasks (Mueller \& Hindin, 2011). Similarly, the results also showed that self-efficacy, creativity perception, and productive disposition had a significant effect on student academic performance for E-learning applications. Balasubramanian, Jaykumar, and Fukey (2014) defines education provided electronically through the internet, internal network (intranet), or through multimedia such as CDs, DVDs, and others providing an opportunity to connect what learning learned in the classroom with activities outside the classroom thereby encouraging students to explore more questions and possibilities. The results of the study confirmed the efficiency of computer-based learning in student involvement, increased learning experience and opportunities for students, increased knowledge and self-awareness (Wilson \& Randall, 2012) increased the achievement in learning outcomes and developed skills for lifelong learning (BeythMarom, Chajut, Roccas, \& Sagiv, 2003).

Model-2 shows that for e-learning applications: (1) Self-efficacy and creativity perception have a significant effect on students' productive dispositions. (2) Self-efficacy has a positive correlation towards productive disposition. (3) The perception of creativity has a positive correlation towards productive disposition. Because there is a positive correlation between self-efficacy and creativity perception on productive disposition, it can be said that these two variables can improve students' productive disposition. Thus, it can be said that self-efficacy and creativity 
perception are important variables in increasing productive disposition. In this research, productive disposition refers to the tendency to view mathematics as reasonable, useful, and valuable knowledge that can be developed through one's own belief, persistence, and abilities.

The application of E-learning in the situation of the Covid-19 outbreak changes students' interest in learning. Model-3 shows that self-efficacy has a direct effect on improving student academic performance for E-learning application. Increased student self-efficacy occurs in science, technology, engineering, and mathematics as a result of student involvement in learning (Van Aalderen-Smeets \& Walma van der Molen, 2018). Self-efficacy is an important aspect in achieving extraordinary achievements in all fields that are explored by students, including academics.

The results showed that the perception of creativity did not have a direct effect on improving student academic achievement for E-learning applications. Creativity perception is not correlated (even with large sample sizes) with various creative problem-solving measures. These findings support the idea that some of the initial requirements are the same for all creative activities such as motivation, intelligence, or environment. The development of productive dispositions can be trained through learning mathematics. Involving mental attitudes and developing mathematical disposition are an effective way to observe situations (Watson \& Hill, 2015). The results showed that productive disposition did not have a direct effect on improving student academic performance for E-learning applications. The negative disposition towards mathematics has affected their performance in doing math tasks (Mueller \& Hindin, 2011).

The results showed that self-efficacy, creativity perception, and productive disposition had a significant effect on student academic performance for E-learning applications. This condition can help them develop metacognition skills such as independent learning and creative performance and generate divergent and convergent questions so as to develop high-order thinking skills of student (Oversby, Sanders, Talib, Thoe, \& Esa, 2019).

\section{CONCLUSION}

Analysis of the role of self-efficacy, creativity perception, and productive disposition in academic performance by using path analysis and is modeled in structural equations. There is a positive correlation between Self-Efficacy and Productive Disposition. There is a positive correlation between creativity perception and productive disposition. There is a direct effect between self-efficacy on academic performance. The self-efficacy factor (for example, being happy to help other friends, daring to face criticism and challenges, and having the courage to compete to win a competition) is one of the most powerful factors to affect student academic performance. Creativity perception (for example, creative ideas must be sophisticated and complex, creative people have high curiosity, creative people find it difficult to accept different opinions from others, creativity can only be developed in certain people, and creativity occurs by chance) has the lowest contribution on academic performance.

Funding: This study received no specific financial support.

Competing Interests: The authors declare that they have no competing interests.

Acknowledgement: Thank you to all the respondents who gave their time, Ministry of

Research and Technology Directorate of Higher Education (KEMENRISTEKDIKTI), and the

Institute for Research and Community Service at Bandung Islamic University, Indonesia.

\section{REFERENCES}

Akyildiz, S. T., \& Celik, V. (2020). Thinking outside the box: Turkish EFL teachers' perceptions of creativity. Thinking Skills and Creativity, 36, 100649.Available at: https://doi.org/10.1016/j.tsc.2020.100649.

Areepattamannil, S., \& Santos, I. M. (2019). Adolescent students' perceived information and communication technology (ICT) competence and autonomy: Examining links to dispositions toward science in 42 countries. Computers in Human Behavior, 98, 50-58.Available at: 10.1016/j.chb.2019.04.005. 
Awofala, A. O., Lawal, R. F., Arigbabu, A. A., \& Fatade, A. O. (2020). Mathematics productive disposition as a correlate of senior secondary school students' achievement in mathematics in Nigeria. International Journal of Mathematical Education in Science and Technology, 1-17.

Balasubramanian, K., Jaykumar, V., \& Fukey, L. N. (2014). A study on "Student preference towards the use of Edmodo as a learning platform to create responsible learning environment. Procedia-Social and Behavioral Sciences, 144(1), 416422.Available at: https://doi.org/10.1016/j.sbspro.2014.07.311.

Bandura, A. (1989). Regulation of cognitive processes through perceived self-efficacy. Developmental Psychology, 25(5), 729735.Available at: https://doi.org/10.1037/0012-1649.25.5.729.

Bandura, A. (2010). Self-efficacy. The Corsini Encyclopedia of Psychology, 1-3,.

Batey, M., \& Furnham, A. (2008). The relationship between measures of creativity and schizotypy. Personality and Individual Differences, 45(8), 816-82 1.Available at: https://doi.org/10.1016/j.paid.2008.08.014.

Beghetto, R. A. (2016). Creative learning: A fresh look. Journal of Cognitive Education and Psychology, 15(1), 6-23.Available at: https://doi.org/10.1891/1945-8959.15.1.6.

Berry, J. W., \& Chew, S. L. (2015). Improving learning through interventions of student-generated questions and concept maps. The teaching of Psychology, 35, 305-312.Available at: https://doi.org/10.1080/00986280802373841.

Bervell, B., \& Umar, I. N. (2017). Validation of the UTAUT model: Re-considering nonlinear relationships of exogenous variables in higher education technology acceptance research. Eurasia Journal of Mathematics, Science and Technology Education, 13(10), 6471-6490.Available at: https://doi.org/10.12973/ejmste/78076.

Beyth-Marom, R., Chajut, E., Roccas, S., \& Sagiv, L. (2003). Internet-assisted versus traditional distance learning environments: Factors affecting students' preferences. Computers \& Education, 41(1), 65-76.Available at: 10.1016/So3601315(03)00026-5.

Bhuasiri, W., Xaymoungkhoun, O., Zo, H., Rho, J. J., \& Ciganek, A. P. (2012). Critical success factors for e-learning in developing countries: A comparative analysis between ICT experts and faculty. Computers $\mathcal{E}^{2}$ Education, 58(2), 843855.Available at: https://doi.org/10.1016/j.compedu.2011.10.010.

Chang, S.-H., Wang, C.-L., \& Lee, J.-C. (2016). Do award-winning experiences benefit students' creative self-efficacy and creativity? The moderated mediation effects of perceived school support for creativity. Learning and Individual Differences, 51, 291-298.Available at: https://doi.org/10.1016/j.lindif.2016.09.011.

Chemers, M. M., Hu, L.-t., \& Garcia, B. F. (2001). Academic self-efficacy and first-year college student performance and adjustment. Journal of Educational Psychology, 93(1), 55-64.Available at: https://doi.org/10.1037/0022-0663.93.1.55.

Chen, C. L., \& Wu, C. C. (2020). Students' behavioral intention to use and achievements in ICT-Integrated mathematics remedial instruction: Case study of a calculus course. Computers \& Education, 145, 103740.Available at: https://doi.org/10.1016/j.compedu.2019.103740.

Cidral, W. A., Oliveira, T., Di Felice, M., \& Aparicio, M. (2018). E-learning success determinants: Brazilian empirical study. Computers $ङ$ Education, 122, 273-290.Available at: 10.1016/j.compedu.2017.12.001.

Cohen, L., Manion, L., \& Morrison, K. (2007). Observation. Research Methods in Education, 6, 396-412.

Dwyer, C. P., Hogan, M. J., Harney, O. M., \& Kavanagh, C. (2017). Facilitating a student-educator conceptual model of dispositions towards critical thinking through interactive management. Educational Technology Research and Development, 65(1), 47-73.Available at: https://link.springer.com/article/10.1007\%2Fs1 1423-016-9460-7.

Dwyer, C. P., Hogan, M. J., \& Stewart, I. (2014). An integrated critical thinking framework for the 21 st century. Thinking skills and Creativity, 12, 43-52.Available at: https://doi.org/10.1016/j.tsc.2013.12.004.

Eisenman, R., \& Grove, M. S. (1972). Self-ratings of creativity, semantic differential ratings, and preferences for polygons varying in complexity, simplicity, and symmetry. The Journal of Psychology, 81(1), 63-67.Available at: https://doi.org/10.1080/00223980.1972.9923789.

Fazlollahtabar, H., \& Muhammadzadeh, A. (2012). A knowledge-based user interface to optimize curriculum utility in an elearning system. International Journal of Enterprise Information Systems, 8(3), 34-53. 
Figueroa-Cañas, J., \& Sancho-Vinuesa, T. (2018). Investigating the relationship between optional quizzes and final exam performance in a fully asynchronous online calculus module. Interactive Learning Environments, 1-11.

Giancarlo, C. A., \& Facione, P. A. (2001). A look across four years at the disposition toward critical thinking among undergraduate students. The Journal of General Education, 50(1), 29-55.

Huang, P. S., Peng, S.-L., Chen, H. C., Tseng, L. C., \& Hsu, L. C. (2017). The relative influences of domain knowledge and domain-general divergent thinking on scientific creativity and mathematical creativity. Thinking Skills and Creativity, 25, 1-9.Available at: https://doi.org/10.1016/j.tsc.2017.06.001.

Huang, N. T., Chang, Y. S., \& Chou, C. H. (2020). Effects of creative thinking, psychomotor skills, and creative self-efficacy on engineering design creativity. Thinking Skills and Creativity, 37, 100695.

Iannone, P., \& Inglis, M. (2010). Self efficacy and mathematical proof: are undergraduate students good at assessing their own proof production ability? Paper presented at the In Proceedings of the 13th Conference on Research in Undergraduate Mathematics Education.

Kanhai, A., \& Singh, B. (2017). Some environmental and attitudinal characteristics as predictors of mathematical creativity. International Journal of Mathematical Education in Science and Technology, 48(3), 327-337.Available at: https://doi.org/10.1080/0020739X.2016.1241435.

Kilpatrick, J., Swafford, J., \& Findell, B. (2001). Adding it up: Helping children learn mathematics. National research council (Ed.) (Vol. 2101). Washington, DC: National Academy Press.

Kohen, Z., Amram, M., Dagan, M., \& Miranda, T. (2019). Self-efficacy and problem-solving skills in mathematics: The effect of instruction-based dynamic versus static visualization. Interactive Learning Environments, 1-20.Available at: https://doi.org/10.1080/10494820.2019.1683588.

Ku, K. Y., \& Ho, I. T. (2010). Metacognitive strategies that enhance critical thinking. Metacognition and Learning, 5(3), 251267.Available at: https://link.springer.com/article/10.1007/s11409-010-9060-6.

Lau, N. S., Lam, L., \& Zhou, B. (2010). Enhancing blended courses to facilitate student achievement of learning outcomes. In International conference on hybrid learning (pp. 205-2 16). Berlin, Heidelberg: Springer.

Lee, D., \& Meara, D. M. (2002). Discrimination of social knowledge and its flexible application from creativity: a multitraitmultimethod approach. Personality and Individual Differences 32(5), 913-928.Available at: https://doi.org/10.1016/S0191-8869(01)00099-X.

Levina, E. Y. (2017). Structure and content of e-learning information environment based on geo-information technologies. EURASIA Journal of Mathematics, Science and Technology Education, 13(8), 5019-5031.Available at: https://doi.org/10.12973/eurasia.2017.00974a.

Liang, L., Yeung, K., Lui, R. K. W., Cheung, W. M. Y., \& Lam, K. F. (2018). Lessons learned from a calculus e-learning system for first-year university students with diverse Mathematics backgrounds. In: Silverman J., Hoyos V. (eds) Distance Learning, ELearning and Blended Learning in Mathematics Education. ICME-13 Monographs. Cham: Springer.

Macpherson, R., \& Stanovich, K. E. (2007). Cognitive ability, thinking dispositions, and instructional set as predictors of critical thinking. Learning and Individual Differences, 17(2), 115-127.Available at: https://doi.org/10.1016/j.lindif.2007.05.003.

Malykh, S. (2017). The role of personality traits and intelligence in academic achievement of russian high school students. Procedia - Social and Behavioral Sciences, 237, 1304-1309.Available at: https://doi.org/10.1016/j.sbspro.2017.02.214.

Mann, E. L. (2009). The search for mathematical creativity: Identifying creative potential in middle school students. Creativity Research Journal, 21(4), 338-348.Available at: https://doi.org/10.1080/10400410903297402.

Maxwell, J. P., Masters, R. S. W., Kerr, E., \& Weedon, E. (2001). The implicit benefit of learning without errors. The Quarterly Journal of Experimental Psychology Section A, 54(4), 1049-1068.Available at: https://journals.sagepub.com/doi/10.1080/713756014.

Mueller, M., \& Hindin, A. (2011). An analysis of the factors that influence preservice elementary teachers' developing dispositions about teaching all children. Issues in Teacher Education, 20(1), 17-34. 
Niu, L., Behar-Horenstein, L. S., \& Garvan, C. W. (2013). Do instructional interventions influence college students' critical thinking skills? A meta-analysis. Educational Research Revierw, 9, 114-128.Available at: https://doi.org/10.1016/j.edurev.2012.12.002.

Oversby, J., Sanders, J., Talib, C. A., Thoe, N. K., \& Esa, N. (2019). Question generating supported by blended learning platform: Issues of social justice for environmental education. EURASIA Journal of Mathematics, Science and Technology Education, 15(5), em1709.

Pajares, F., \& Miller, M. D. (1994). Role of self-efficacy and self-concept beliefs in mathematical problem solving: A path analysis. Journal of Educational Psychology, 86(2), 193-203.Available at: https://doi.org/10.1037/0022-0663.86.2.193.

Pluck, G. (2016). Separate contributions of general intelligence and right prefrontal neurocognitive functions to academic achievement at the university level. Trends in Neuroscience and Education, 5(4), 178-185.Available at: https://doi.org/10.1016/j.tine.2016.07.002.

Prior, D. D., Mazanov, J., Meacheam, D., Heaslip, G., \& Hanson, J. (2016). Attitude, digital literacy and self efficacy: Flow-on effects for online learning behavior. The Internet and Higher Education, 29, 91-97.Available at: https://doi.org/10.1016/j.iheduc.2016.01.00.

Puente-Díaz, R., \& Cavazos-Arroyo, J. (2017). Creative self-efficacy: The influence of affective states and social persuasion as antecedents and imagination and divergent thinking as consequences. Creativity Research Journal, 29(3), 304312.Available at: https://doi.org/10.1080/10400419.2017.1360067.

Quinn, S., Hogan, M., Dwyer, C., Finn, P., \& Fogarty, E. (2020). Development and validation of the student-educator negotiated critical thinking dispositions scale (SENCTDS). Thinking Skills and Creativity, 38, 100710.Available at: https://doi.org/10.1016/j.tsc.2020.100710.

Roni Reiter-Palmon. (2012). Evaluation of self-perceptions of creativity: Is it a useful criterion? Creativity Research Journal, 24(23), 107-1 14.Available at: http://dx.doi.org/10.1080/10400419.2012.676980.

Royster, D. C., Kim Harris, M., \& Schoeps, N. (1999). Dispositions of college mathematics students. International Journal of Mathematical Education in Science and Technology, 30(3), 317-333.Available at: https://doi.org/10.1080/002073999287851.

Saija, L. M. (2012). Analyzing the mathematical disposition and its correlation with mathematics achievement of abstract senior high school students. Infinity Journal, 1(2), 148-152.

Sangsuk, P., \& Siriparp, T. (2015). Confirmatory factor analysis of a scale measuring creative self-efficacy of undergraduate students. Procedia-Social and Behavioral Sciences, 171, 1340-1344.Available at: https://doi.org/10.1016/j.sbspro.2015.01.251.

Sansome, E. J. (2016). Building teachers' pedagogy practices in reasoning, to improve students' dispositions towards mathematics. Doctoral Dissertation, Queensland University of Technology.

Seppala, M., Caprotti, O., \& Xambó, S. (2006). Using web technologies to teach mathematics. Paper presented at the In Society for Information Technology \& Teacher Education International Conference. Association for the Advancement of Computing in Education.

Stevens, T., Olivarez, A., Lan, W. Y., \& Tallent-Runnels, M. K. (2004). Role of mathematics self-efficacy and motivation in mathematics performance across ethnicity. The Journal of Educational Research, 97(4), 208-222.Available at: https://doi.org/10.3200/JOER.97.4.208-222.

Stupnisky, R. H., Renaud, R. D., Daniels, L. M., Haynes, T. L., \& Perry, R. P. (2008). The interrelation of first-year college students' critical thinking disposition, perceived academic control, and academic achievement. Research in Higher Education, 49(6), 513.Available at: https://doi.org/10.1007/s11162-008-9093-8.

Talsma, K., Schüz, B., Schwarzer, R., \& Norris, K. (2018). I believe, therefore I achieve (and vice versa): A meta-analytic crosslagged panel analysis of self-efficacy and academic performance. Learning and Individual Differences, 61, 136150.Available at: https://doi.org/10.1016/j.lindif.2017.11.015. 
Thomas, C. L., Cassady, J. C., \& Heller, M. L. (2017). The influence of emotional intelligence, cognitive test anxiety, and coping strategies on undergraduate academic performance. Learning and Individual Differences, 55, 40-48.Available at: https://doi.org/10.1016/j.lindif.2017.03.001.

Thompson, J. (2009). Performance affects: Applied theatre and the end of effect: Springer.

Tyagi, T. K. (2016). Is there a causal relation between mathematical creativity and mathematical problem-solving performance? International Journal of Mathematical Education in Science and Technology, 47(3), 388-394.Available at: https://doi.org/10.1080/0020739X.2015.1075612.

Van Aalderen-Smeets, S., \& Walma van der Molen, J. H. (2018). Modeling the relation between students' implicit beliefs about their abilities and their educational STEM choices. International Journal of Technology and Design Education, 28(1), 127.Available at: https://doi.org/10.1007/s10798-016-9387-7.

Vogel, F. R., \& Human-Vogel, S. (2016). Academic commitment and self-efficacy as predictors of academic achievement in additional materials science. Higher Education Research \& Development, 35(6), 1298-1310.Available at: https://doi.org/10.1080/07294360.2016.1144574.

Wagster, J., Tan, J., Wu, Y., Biwas, G., \& Schwartz, D. (2007). Do learning by teaching environments with metacognitive support help students develop better learning behaviors? Paper presented at the In Proceedings of the Annual Meeting of the Cognitive Science Society.

Wakeford, C. (2011). Evolution of e-learning projects: A creative experience? Bioscience Education, 18(1), 1-10.Available at: https://doi.org/10.3 108/beej.18.2.

Wang, Y. L., Liang, J. C., Lin, C. Y., \& Tsai, C. C. (2017). Identifying Taiwanese junior-high school students' mathematics learning profiles and their roles in mathematics learning self-efficacy and academic performance. Learning and Individual Differences, 54, 92-101.Available at: https://doi.org/10.1016/j.lindif.2017.01.008.

Watson, J., \& Hill, A. (2015). Dictionary of media and communication studies. USA: Bloomsbury Publishing.

Wilson, G., \& Randall, M. (2012). The implementation and evaluation of a new learning space: A pilot study. Research in Learning Technology, 20(2), n2.

Zangenehvandi, M., Farahian, M., \& Gholami, H. (2014). On the relationship between efl teachers'critical thinking and selfefficacy. Modern Journal of Language Teaching Methods, 4(2), 286.

Zeidner, M., \& Matthews, G. (2000). Intelligence and personality (hilangkan).

Zhou, C., Chen, H., \& Luo, L. (2014). Students' perceptions of creativity in learning Information Technology (IT) in project groups. Computers in Human Behavior, 41, 454-463.Available at: https://doi.org/10.1016/j.chb.2014.09.058.

Zimmerman, B. J., \& Cleary, T. J. (2006). Adolescents' development of personal agency: In F. Pajares, \& T. Urdan (Eds.), Adolescence and Education: Self-Efficacy Beliefs of Adolescents (Vol. 5, pp. 45-69). Greenwich, CT: Information Age Publishing.

Views and opinions expressed in this article are the views and opinions of the author(s), International Journal of Education and Practice shall not be responsible or answerable for any loss, damage or liability etc. caused in relation to/arising out of the use of the content. 